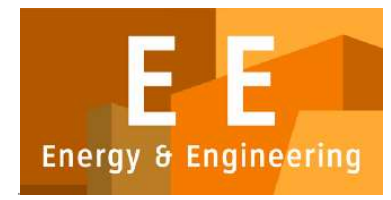

PAPER - OPEN ACCESS

\title{
Semangat Reso Dalam Rumah Panggung Bugis Saoraja Masa Sekarang
}

\author{
Author : Munarsi M dan Djoko Wijono \\ DOI $\quad: 10.32734 /$ ee.v3i1.874 \\ Electronic ISSN $\quad: 2654-704 X$ \\ Print ISSN : $2654-7031$
}

Volume 3 Issue 1 - 2020 TALENTA Conference Series: Energy \& Engineering (EE)

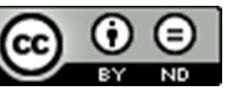

This work is licensed under a Creative Commons Attribution-NoDerivatives 4.0 International License.

Published under licence by TALENTA Publisher, Universitas Sumatera Utara

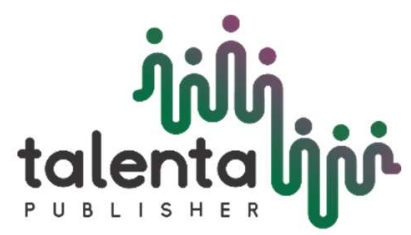




\title{
jibiti (a) TALENTA Conference Series
}

Available online at https://talentaconfseries.usu.ac.id/ee

\section{Semangat Reso Dalam Rumah Panggung Bugis Saoraja Masa Sekarang}

\author{
The spirit of Reso in the Saoraja Bugis Stage House Today \\ Munarsi $\mathrm{M}^{1}$, Djoko Wijono ${ }^{2}$ \\ ${ }^{1}$ Mahasiswa Program Magister Arsitektur, Fakultas Teknik, Universitas Gadjah Mada \\ ${ }^{2}$ Program Studi Arsitektur, Fakultas Teknik, Universitas Gadjah Mada Jl. Grafika No.2, Senolowo, Sinduadi, Kec. Mlati, Kabupaten Sleman, \\ Daerah Istimewa Yogyakarta 55284, Indonesia \\ cicimunandar@gmail.com
}

\begin{abstract}
Abstrak
Rumah tinggal melalui arsitektur dan ruangnya kerap menjadi media untuk mengekspresikan nilai yang dianut masyarakat penghuninya. Masyarakat Bugis di Kecamatan Baranti menjadikan rumah panggung model tradisional sebagai pilihan utama huniannya. Fenomena yang ditemukan di lapangan yaitu rumah panggung yang dibangun masyarakat hadir dengan langgam yang mengadopsi bentuk-bentuk rumah bangsawan kalangan raja (saoraja). Penelitian ini bertujuan untuk mencari pemaknaan melalui fenomena dan karakteristik arsitektur rumah panggung saoraja di Kecamatan Baranti Kabupaten Sidrap. Karakteristik arsitektur rumah panggung saoraja dipahami berdasarkan analisis kualitatif melalui observasi dan wawancara mendalam kepada pemilik rumah. Bentuk dan karakteristik fasad, material yang digunakan, dimensi rumah dan ruang tamu merupakan tema-tema yang menjadi karakteristik rumah panggung saoraja. Tema-tema tersebut kemudian dirumuskan dan dicari keterkaitannya dengan latar belakang dan pandangan-pandangan pemilik rumah. Fenomena arsitektur dan keruangan tersebut dianalisis secara induktif sehingga menjurus pada satu makna. Hasil analisa menemukan bahwa ruang dan arsitektur rumah panggung saoraja merupakan wahana untuk mengekspresikan semangat reso.
\end{abstract}

Kata kunci: Arsitektur, Rumah Panggun, Bugis, Reso

\begin{abstract}
Houses through architecture and space are often the media to express the values adopted by the inhabitants. The Bugis community in Baranti sub-district has made traditional model houses as their first choice of residence. The phenomenon found in the field is that houses on stilts built by the community come with a style that adopts the forms of royal houses of the king (saoraja). This study aims to find meaning through phenomena and architectural characteristics of Saoraja stage houses in Baranti District, Sidrap Regency. The architectural characteristics of the Saoraja stage house are understood based on qualitative analysis through observation and indepth interviews with homeowners. The shape and characteristics of the facade, the materials used, the dimensions of the house and living room are the themes that characterize the Saoraja stage house. The themes are then formulated and their relationship is sought with the background and views of the homeowner. These architectural and spatial phenomena are analyzed inductively so that they lead to one meaning. The results of the analysis found that the space and architecture of the Saoraja Stage House is a vehicle to express the spirit of Reso.
\end{abstract}

Keywords: Architecture, House on stilts, Bugis, Reso

(C) 2020 The Authors. Published by TALENTA Publisher Universitas Sumatera Utara Selection and peer-review under responsibility of Seminar Nasional Kearifan Lokal V 2020 p-ISSN: 2654-7031, e-ISSN: 2654-704X, DOI: 10.32734/ee.v3i1.874 


\section{Pendahuluan}

Indonesia merupakan negara kepulauan yang kaya akan keragaman budaya. Setiap daerah di Indonesia memiliki keragaman arsitektur vernakular yang dipengaruhi oleh berbagai aspek sosial-budaya dan tradisi masing-masing tempat [1]. Namun demikian, zaman berubah. arsitektur vernakular mengalami perubahan juga pertumbuhan. Kemanjuan teknologi masa sekarang menciptakan modernisasi, sedangkan tradisi dan moderenisasi merupakan dua sisi mata uang, dimana keduanya menentukan nilai sebuah perubahan [2]. Di beberapa daerah di Indonesia ada kecenderungan masyarakat meninggalkan rumah-rumah model tradisional. Keberadaan model arsitektur rumah tradisional cenderung stagnan dan dianggap tidak dapat memenuhi tuntutan dinamis kehidupan yang selalu berubah dengan cepat [3].

Salah satu masyarakat yang masih mempertahankan identitas arsitektur tradisionalnya adalah masyarakat Bugis. Berdasarkan grand tour yang pernah dilakukan, di Kecamatan Baranti, Kabupaten Sidrap, Provinsi Sulawesi Selatan masyarakat Bugis masih menjadikan rumah panggung model tradisional sebagai pilihan utama huniannya. Rumah-rumah panggung yang digunakan masa sekarang terindikasi mengalami pergeseran tanda dan makna. Fenomena yang ditemukan di lapangan yaitu rumah panggung yang dibangun masyarakat hadir dengan langgam yang mengadopsi bentuk-bentuk rumah bangsawan kalangan raja (saoraja). Namun demikian, saat ini nampaknya rumah panggung saoraja tidak lagi terikat dengan sistem strata sosial yang sesuai dengan nilai-nilai dan kaidah lama (ade), heterogenitas strata sosial baik itu kalangan bangsawan maupun rakyat biasa tidak berpengaruh pada bentuk maupun perlambangan identitas rumah mereka.

Oleh karena itu, penelitian ini mengangkat fenomena rumah panggung saoraja sebagai objek kajian. Tujuan penelitian ini adalah untuk mencari pemaknaan melalui fenomena dan karakteristik arsitektur rumah panggung saoraja di Kecamatan Baranti Kabupaten Sidrap.

\section{Landasan Teori}

Landasan teori dalam penelitian ini berfungsi sebagai latar belakang pengetahuan teoritik atau background knowledge. Teori-teori tersebut bukan sebagai intsrumen pengarah jalannya penelitian melainkan menggambarkan batasan-batasan dan area yang menjadi fokus penelitian.

\subsection{Tradisi Arsitektur Vernakular Masa Sekarang}

Kata tradisi berasal dari bahasa Latin 'traditonem' yaitudelivery, surrender, a handing down, a giving up (Etymology Dictionary). Tradisi adalah sebuah praktek, kebiasaan, atau cerita yang dihafalkan dan diwariskan dari generasi ke generasi [1]. Sedangkan arsitektur vernakular adalah "anonymous, indigenous, naïve, naif, premitive, rude, popular spontaneous, local or folk based". [4]; atau juga dikenal sebagai "architecture without architect";non-formal arsitektur, yaitu arsitektur yang khas dari suatu masyarakat tanpa diketahui siapa arsiteknya [5]. Arsitektur vernakular terbentuk dari cara-cara trial and error, yang mana bila berlangsung berulang-ulang, diakui dan dirujuk melalui pola estafet turun temurun, vernakular akan menjadi tradisi yang mengandung berbagai aspek seperti pakem-doktrin, mistis, budaya, sosial, agama, kekuasaan, bahasa dan adat [1].

Sejak kemunculan teori vernakular, banyak pihak yang berusaha mengangkat kembali bangunan-bangunan vernakular untuk diadaptasi di masa sekarang. Namun, arsitektur yang dulunya penuh makna filosofi diungkapkan hanya sebatas bayang-bayang visualisasi semata, berwujud tradisional tapi tak bermakna, tidak mengindahkan pada tatanan dan hirarki makna [1].

\subsection{Arsitektur sebagai Media Ekspresi}

Ekspresi Menurut Kamus Besar Bahasa Indonesia Pusat bahasa2012 adalah pengungkapan atau proses menyatakan (yaitu memperlihatkan atau menyatakan maksud, gagasan, perasaan dan sebagainya). Ekspresi menurut kamus Webster adalah transforming (transformasi); showing (menunjukkan); representing (mewakili); putting (menempatkan); 
conveying (menyampaikan); feeling (merasa). Pengertian ekspresi dalam disiplin ilmu arsitektur mencakup tiga komponen yaitu pesan, media, dan penerima [6].

Identitas diri yang terbentuk dari pikiran dan nilai-nilai dikomunikasikan secara tidak langsung, melainkan diungkapkan menggunakan simbol-simbol [7]. Tanda dan simbol digunakan dalam karya-karya arsitektur sebagai media yang tampil baik dalam pengertian tersurat maupun dalam pengertian tersirat yang mewakili kiasan atau makna tertentu [8]. Rumah tradisional masyarakat Jawa misalnya, melalui ekspresi bentuk simbol karya arsitektur dari konsep tata ruang hingga elemen fisik buatan merupakan ungkapan orientasi diri dan refleksi sikap hidup yang selanjutnya pesan tersebut dapat diapresiasi/diinterpretasi secara bebas oleh siapa saja dan kapan saja tanpa perlu diterima sekaligus [8]. Beberapa variabel arsitektur yang mengandung makna dan dijadikan simbol, menurut Lang 1987 [8]. adalah sebagai berikut:

- Konfigurasi bangunan: Dalam budaya tertentu bentuk-bentuk dan pola-pola dari gaya arsitektur memiliki makna tertentu tergantung pada kesepakatan sosial dan kepercayaan yang dianut.

- Konfigurasi spasial: menyangkut volume, proporsi dan batasa, misalnya orang yang berasal dari status ekonomi dan sosial tinggi, ukuran ruang yang digunakannya lebih luas dari orang yang berasal dari status ekonomi dan sosial yang rendah.

- Material: material tertentu selalu dihubungkan dengan tipe bangunan tertentu.

- Warna, seperti warna emas simbol kemakmuran, kejayaan dan kekuasaan.

- Aspek non visual: seperti suara

Aspek non fisik: seperti nama tempat, misal brand komplek perumahan sebagai simbol status sosial.

\section{Metode Penelitian}

Penelitian ini menggunakan metode kualitatif dengan pendekatan naturalistik dengan menarik kesimpulan secara induksi. Perumusan teori pendekatan naturalistik didasarkan pada fakta empiris di lapangan, bukan berdasarkan teori yang telah ada. Pengumpulan data dilakukan dengan teknik observasi dan wawancara mendalam untuk mengungkankan makna.

Penelitian ini mengangkat 5 kasus rumah bangsawan dan 5 kasus rumah rakyat biasa yang tersebar di 9 desa/kelurahan di Kecamatan Baranti Kabupaten Sidrap. Kasus yang diangkat adalah rumah-rumah panggung dengan langgam yang mengadopsi bentuk-bentuk saoraja. Selanjutnya, penelitian ini menggunakan proses analisa fisik-non fisik, yaitu dimulai dengan menganalisa terhadap karakter fisik arsitektur dan keruangan kemudian menjurus kepada makna/nilai

\section{Hasil dan Pembahasan}

Masyarakat Bugis di Kecamatan Baranti Kabupaten Sidrap, mengenal sistem penggolongan strata sosial diperoleh dari garis keturunan atau dari perkawinan silang yang telah ditentukan secara tradisi adat (ade), diantaranya adalah golongan bangsawan yang bergelar Petta/ Andi dan golongan masyarakat biasa yaitu dari kalangan menengah bergelar pung/puang dan kalangan bawah bergelar iye/uwa'. Sistem ini bersifat statis dan tidak dapat berubah. Penelitian ini mengangkat kasus rumah panggung yang mengadopsi bentuk-bentuk saoraja (rumah kaum bangsawan masyarakat Bugis tradisional)dengan latar belakang penghuni dari kalangan bangsawan dan juga rakyat biasa.

Hasil penelitian menemukan bahwa nilai keistimewaan rumah panggung saoraja tidaklah berubah, rumah panggung saoraja bagi masyarakat Bugis masa sekarang tetap dipandang sebagai arsitektur yang ekslusif. Namun, pengguna langgam saoraja tidak terbatas pada kalangan ningrat tetapi menjadi gaya yang bebas digunakan oleh siapa saja. Artinya pesan yang menjadi substansi dari perwujudan arsitektur saoraja tidak hanya mengekspresikan strata sosial yang didapatkan melalui proses pewarisan semata.

Dialog antar tema menemukan satu kesimpulan bahwa arsitektur rumah panggung di Kecamatan Baranti selain memiliki fungsi utama sebagai hunian juga merupakan media ekspresi semangat reso. Ada ungkapan di tengah masyarakat Bugis yang berbunyi "Resopa Temangingngi' Namalomo Naletei Pammase Dewata" artinya, hanya dengan usaha/kerja keras yang tidak berkesudahan-lah yang mudah mendapatkan rahmat dari Dewa (Tuhan YME). Dari 
ungkapan tersebut, reso diangkat dari terminologi Bahasa Bugis yang artinya 'usaha atau kerja keras. Reso dapat dimaknai sebagai serangkaian perjuangan melalui pendidikan, ekonomi dan pekerjaan guna meningkatkan strata sosial dan kualitas hidup seseorang di tengah masyarakat. Sehingga, baik golongan bangsawan maupun rakyat biasa melalui semangat reso melakukan serangkaian upaya dan kerja keras seperti peningkatan finansial/ekonomi, pendidikan dan pekerjaan. Melalui semangat reso golongan bangsawan berusaha mempertahankan eksistensi mereka di tengah masyarakat, sedangkan golongan rakyat biasa melakukan usaha reso guna mendapat pengakuan dan mencapai derajat strata sosial yang lebih tinggi. Konsep substansi yang menjadi ciri dan identitas rumah panggung saoraja dibangun dari beberapa tema-tema temuan fisik. Diantaranya adalah melalui bentuk dan karakteristik fasad, material, dimensi rumah, dan melalui ruang tamu.

\subsection{Bentuk dan karakteristik fasad}

Fasad merupakan bagian paling menonjol dari semua komponen arsitektur rumah panggung Bugis. Komposisi fasad rumah panggung saoraja pada umumnya simetris dengan timpa laja dan tangga sapana sebagai sumbu tengahnya. Dalam masyarakat Bugis tradisional, susunan timpa laja pada atap merupakan simbol stratifikasi sosial masyarakatnya. Semakin tinggi atau semakin banyak susunan timpa laja, maka semakin tinggi pula strata sosial yang disandang pemilik rumah. Timpa laja bersusun lima khusus untuk para raja, bersusun empat dan tiga khusus untuk keturunan bangsawan, sedangkan timpa laja bersusun dua atau satu untuk golongan masyarakat biasa. Tidak ada perbedaan penggunaan jumlah susunan timpa laja antara golongan bangsawan dan yang bukan bangsawan. Tercatat lima kasus rumah bangsawan dan lima kasus rumah bukan bangsawan semuanya memiliki susunan timpa laja dengan jumlah variatif. Timpa laja bersusun dua seyogyanya hanya digunakan untuk rumah rakyat biasa ditemukan pada rumah bangsawan. Di sisi lain, timpa laja bersusun tiga hingga lima yang dahulu digunakan untuk rumah-rumah bangsawan ditemukan di rumah-rumah rakyat biasa.

Selain atap dan susunan tutup bubungan, bentuk tangga juga menjadi salah satu penanda status sosial pemilik rumah masyarakat Bugis Tradisional. Lazimnya tangga utama bagian depan rumah masyarakat berbentuk melintang menerus dari arah kiri ke kanan menuju teras (lego-lego). Model tangga yag digunakan pada kasus penelitian ini adalah tangga sapana. Tangga sapana adalah model tangga bertingkat dengan atap baruga di atasnya. Tangga sapana dulunya hanya digunakan oleh kalangan bangsawan Bugis. Penelitian ini menemukan bahwa tidak ada perbedaan penggunaan jumlah susunan timpa laja dan penggunaan model tangga antara golongan bangsawan dan yang bukan bangsawan.

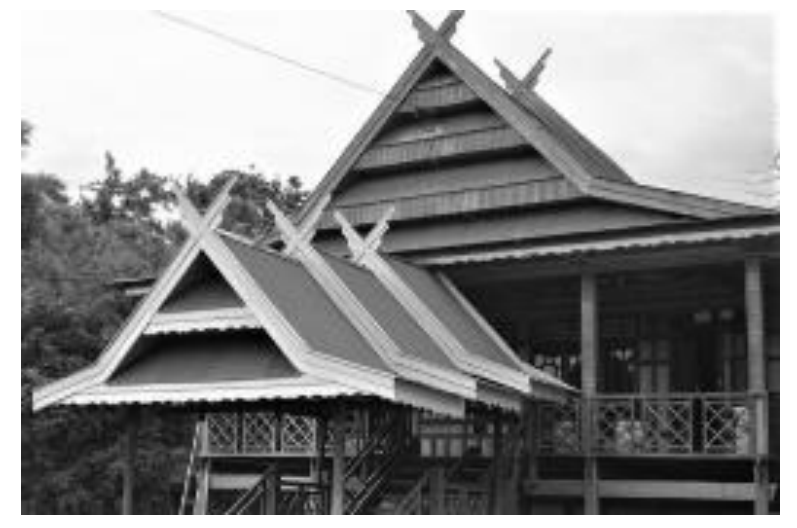

Gambar 1. Rumah kalangan masyarakat biasa menggunakan timpa laja bersusun 4

Kalangan bangsawan menggunakan timpa laja bersusun dan tangga sapana untuk mempertahankan identitas mereka. Sedangkan kalangan masyarakat biasa menggunakan model tersebut sebagai bentuk ekspresi semangat reso. Beberapa faktor yang menjadi alasan fenomena tersebut terjadi yaitu tidak adanya sanksi sosial dari masyarakat, di sisi lain kalangan bangsawan tidak mempermasalahkan hal tersebut, mereka menerima fenomena tersebut sebagai sebuah 
keniscayaan dan menghargai sebagai bagian dari perubahan zaman. Pernyataan narasumber dari golongan bangsawan mengindikasikan bahwa terjadi kohesi sosial, yaitu adanya pemakluman dari masyarakat golongan bangsawan ketika simbol-simbol mereka digunakan oleh masyarakat bukan bangsawan.

\subsection{Material yang digunakan}

Semangat reso terlihat dari pemilihan struktur/konstruksi dan material bangunan yang digunakan. Selain karena faktor fungsi, penggunaan-penggunaan material kayu bermutu kelas satu, penggunaan jendela berbahan kaca, dan konstruksi beton merupakan salah satu upaya yang mencerminkan kemapanan finansial pemilik rumah. Rumah Bugis terbagi dari dua jenis bahan dan material yaitu rumah kayu pada bangunan utama (bola aju) dan rumah beton pada bangunan tambahan (bola batu). Pada struktur utama rumah panggung kayu terdiri dari komponen-komponen yang menggunakan material kayu kelas satu dan material-material yang sedang berkembang (tren/modern). Semua komponen utama rumah panggung kayu saoraja yaitu tiang (aliri), balok (arateng \& pattolo), konstruksi dinding, dan tanggamenggunakan material ulin/ аји sерри (kelas 1A) belakangan rumah-rumah yang dibangun tahun 2010 hingga sekarang menggunakan kayu kayu kumea (kelas 1B). Sedangkan komponen lainnya seperti lantai dan rangka atap menggunakan material kayu kelapi (kelas 1B). Diding ruang dalam menggunakan material kayu uru (kelas 1B) berbentuk lembar seri, material lembar seri juga digunakan untuk menutup tiang dan sebagai bahan utama penutup laingit-langit/plafon. Pada atap menggunakan material seng atau genteng metal memberikan kesan modern.

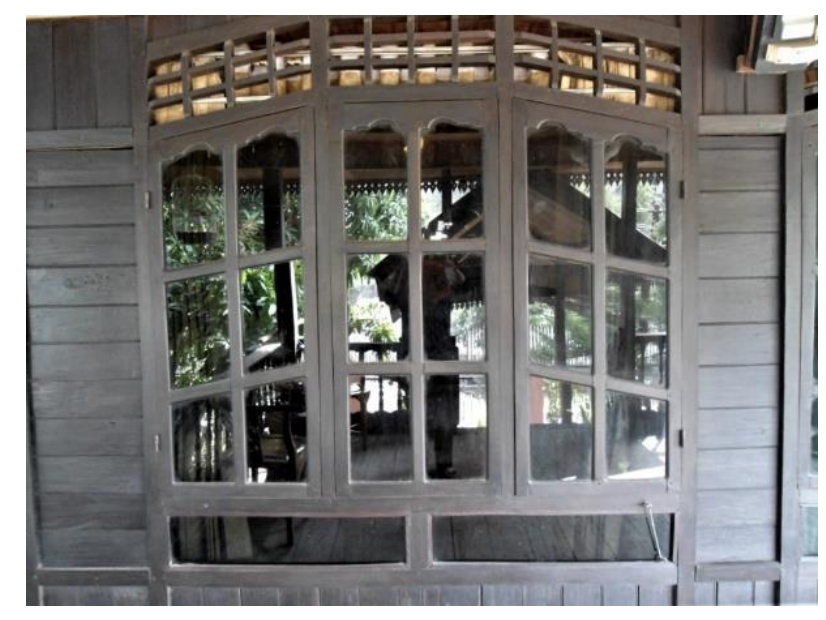

Gambar 2. Material dinding kayu ulin dan jendela kaca

Konstruksi dan material yang bermutu membutuhkan persiapan keuangan yang berkesinambungan. Material dinding dengan bukaan jendela kaca juga sarana menunjukkan kelas sosial penghuninya Ketika pemilik rumah memiliki kemampuan secara finasial, dinding yang awalnya hanya papan kayu diganti dengan dinding yang dilengkapi dengan jendela kaca. Selain itu adanya tren bangunan tambahan menggunakan material beton, hal tersebut juga ditunjang dari kemampuan finansial. Oleh karena itu, melalui konstruksi dan bahan yang bermutu, pemilik rumah ingin memberitahu kepada orang-orang yang bahwa ia adalah pekerja keras (pakkareso) dan jauh dari sifat malas..

\subsection{Dimensi Rumah}

Dimensi rumah merefleksikan kemampuan finansial masing-masing individu pemilik rumah, baik dari kalangan bangsawan maupun rakyat biasa. Dimensi rumah bergantung pada jumlah tiang tambahan dan luasnya bangunan tambahan. Semakin banyak tiang yang digunakan dan semakin besar dimensi bangunan beton maka semakin mahal biaya pembangunan rumah. Rumah panggung biasa lazimnya hanya menggunakan paling banyak 24 tiang dengan jumlah ruang utama sebanyak tiga lontang ditambah lego-lego (teras). Rumah-rumah panggung saoraja di Kecamatan Baranti menggunakan tiang kayu sebanyak 24 hingga 32 buah tiang. Jarak antar tiang kayu melintang 1,7 m hingga 2,2 
m sedangkan jarak antar tiang membujur adalah 2,9 m hingga 3,97 m. Selain itu adanya fenomena bangunan tambahana tapping, yang terletak di samping kanan-belakang bangunan pangggung utama. Pada masa-masa awal pembangunan rumah, rumah hanya terdiri dari bangunan utama dengan 3 bagian lontang. Ketika pemilik rumah memiliki kemampuan secara ekomi, ditambahkannya bangunan tambahan dari meterial beton (bola batu) yang difungsikan sebagai area servis.

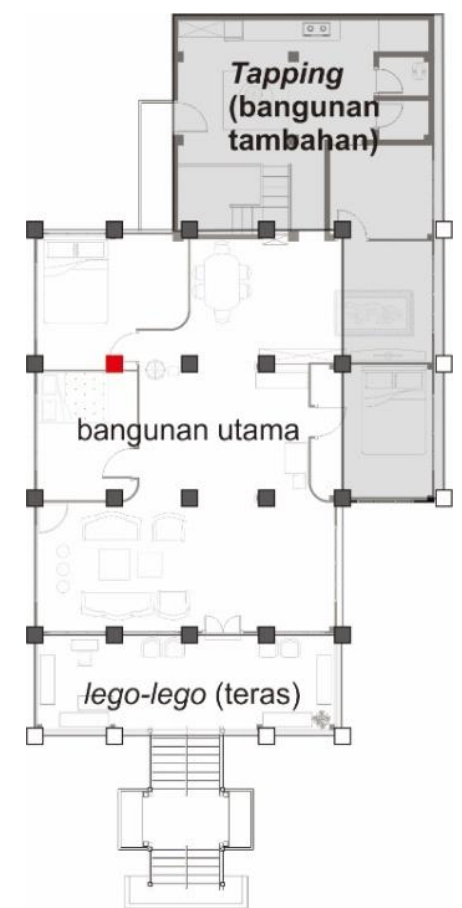

Gambar 3. Bangunan beton tambahan di sisi kanan dan belakang bangunan utama

\subsection{Ruang tamu}

Ruang tamu menguatkan pesan yang sudah disampaikan sebelumnya melalui fasad rumah Bugis (eksterior). Ruang tamu bersifat publik dan dapat diakses oleh siapa saja, terutama untuk tamu-tamu yang diterima secara formal. Ekspresi yang ditampilkan ruang tamu rumah-rumah panggung saoraja di Kecamatan Baranti memiliki kesan mewah. Jika fasad rumah dengan karakteristik arsitektur bersifat seragam, maka ruang tamu adalah media ekpresi yang bersifat individual yang juga dipengaruhi oleh kecenderungan dan kesenangan masing-masing pemilik rumah, meskipun kesan yang ditampilkan hampir sama.

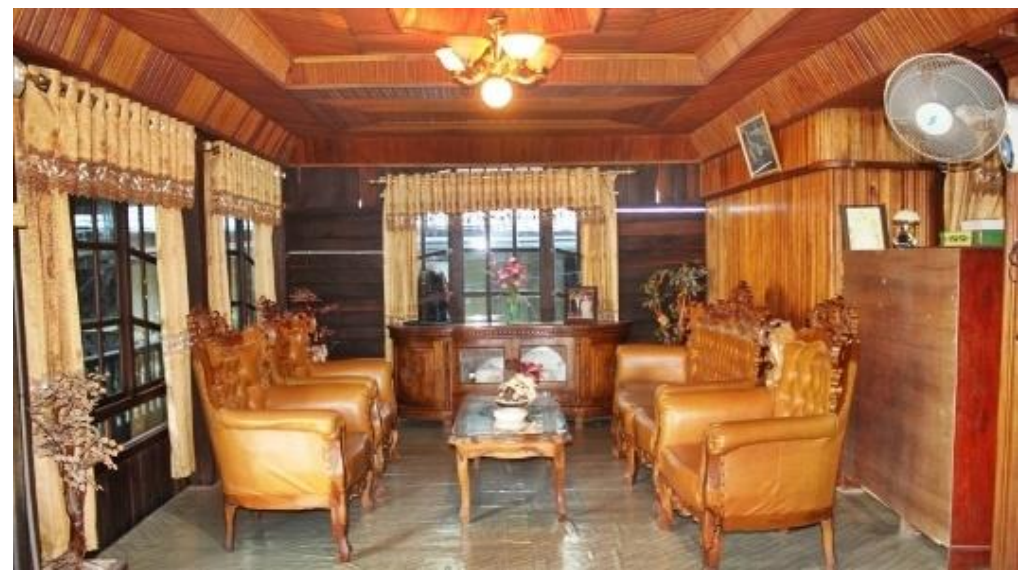

Gambar 4. Suasana ruang tamu rumah panggung Bugis 
Elemen-elemen pembentuk ruang tamu masyarakat Bugis dapat merepresentasikan status sosial dan kedudukan pemilik rumah. Pemilik rumah berusaha menyampaikan identitas dirinya melalui benda-benda yang dipajang di ruang tamu. Pemajangan aksesoris kalifrafi pada beberapa kasus menunjukkan ekspresi identitas kepercayaan agama. Pemajangan aksesoris dari haji seperti koleksi gelas dan cangkir di lemari sudut dan lemari pajangan pada kasus 2, kasus 9, dan kasus 3 menunjukkan status kehajian pemilik rumah. Pemajangan foto keluarga di hampir semua kasus menunjukkan identitas anggota keluarga. Pada kasus 6 pemajangan koleksi tas dan sepatu serta koleksi bernilai lainnya di lemari pajangan depan pintu menunjukkan gaya hidup dan aktialisasi diri. Pemajangan piala dan piagam di ruang tamu penunjukkan prestasi diri anggota keluarga. Memajang koleksi barang mewah, pemilihan jenis perabot dan furnishing merupakan tanda bahwa ruang tamu dibuat seolah-olah sebagai lemari kaca, semua nampak ingin ditunjukkan untuk tamu. Pemilik rumah senantiasa up to date (mengikuti tren yang berkembang) di tengah masyarakat, tanda tersebut dilihat dari penggunaan material plafon lembar seri dan pemilihan perabot yang bernilai historis dari waktu ke waktu dengan pola yang cenderung sama. Penggunaan perabot klasik ukir jepara di semua ruang tamu, perabot tersebut dainggap barang yang dapat memenuhi kebutuhan prestise, sehingga ada kebanggaan tersendiri bagi pemilik rumah ketika memiliki perabot ukir tersebut.

\section{Kesimpulan}

Hasil penelitian menemukan bahwa arsitektur rumah pangung saoraja di Kecamatan Baranti masa sekarang tetap dipandang sebagai arsitektur yang ekslusif namun tidak terbatas pada kalangan bangsawan saja. Esensi dari karakteristik arsitektur rumah panggung saoraja menampilkan sisi semangat reso. Reso dapat dimaknai sebagai serangkaian perjuangan guna meningkatkan strata sosial dan kualitas hidup seseorang di tengah masyarakat. Baik golongan bangsawan maupun rakyat biasa melalui semangat reso melakukan upaya dan kerja keras seperti peningkatan finansial/ekonomi, pendidikan dan pekerjaan. Semangat reso tersebut kemudian diungkapkan melalui elemen-elemen arsitektur, diantaranya adalah:

- Karakteristik fasad: melalui penggunaan tangga sapana dan timpa laja bersusun merepresentasikan rumah yang ekslusif.

- Material rumah kayu ulin, jendela kaca, modern, dan mengikuti tren menunjukkan kelas sosial penghuninya.

- Dimensi rumah: semakin banyak tiang yang digunakan dan semakin besar dimensi bangunan beton maka semakin mahal biaya pembangunan rumah.

- Ruang tamu: pemilik rumah berusaha menyampaikan identitas dirinya melalui benda-benda yang dipajang di ruang tamu

\section{Referensi}

[1] Suharjanto, Gotot,2011. Membandingkan Istilah Arsitektur Tradisional Versus Arsitektur Vernakular: Studi Kasus Bangunan Minangkabau dan Bangunan Bali. Comtech, Volume 2, No. 2, Desember 2011: 592-602.

[2] Wiranto, 1999. Arsitektur Vernakular Indonesia: Perannya dalam Pengembangan Jati Diri.Dimensi Teknik Arsitektur. Volume 27, No. 2, Desember 1999: 15-20.

[3] Hidayat, R., Amalia, L., Sakti, M., Faqih, M. dan Hayati, A., 2013.The Expression of Social Status on House Form (Case: BugisMakassar Modern House).International Journal of Scientific \& Engineering Research Volume 4, Issue3, March-2013.

[4] Papanek, Victor, 1995. The Green Imperative. Ecology and Ethics in Design and Architecture.Thames and Hudson, pp.113-138.

[5] Rudofsky, Bernard,1964. Architecture without Architects. New York: Museum of Modern Art

[6] Muchamad, B. Noor \& Ikaputra, 2010.Model Ekspresi Arsitektur. Makalah, dipresentasikan dalam Seminar Nasional "Metodologi Riset dalam Arsitektur" di Universitas Udayana Denpasar Bali, 3 Juni 2010.

[7] Pitani, Titis S., 2007. Reproduksi Simbolik Arsitektur Tradisional Jawa: Memahami Ruang Hidup Material Manusia Jawa. Gema Teknik- Nomor 2/Tahun X Juli 2007.

[8] Harisah, Afifah \& Masiming, Zulfitria, 2008. Persepsi Manusia Terhadap Tanda, Simbol dan Spasial. Jurnal Smartek, Volume 6, No. 1, Pebruari 2008: 29-43.

[9] Rapoport, Amos, 1969. House Form and Culture. Prentice-Hall, Inc. Engelwood Cliffs N.J, USA

[10] Ismail, Wan Hasimah Wan, 2013. Adoption of Culture in Bugis Houses in Johor Malaysia. Journal of Asian Behavioural Studies, Volume 3, No. 9, Maret/April 2013.

[11] Pelras, Christian, 2006.Manusia Bugis (cetakan pertama terjemahan 'The Bugis” 1996). Nalar \& Forum Jakarta-Paris, Jakarta.

[12] Pole, MY., Mone, AC. \& Rizal, H., 1998.Mengenal Istana Tamalate: Rumah Adat Suku Makassar” Gama University Press, Yogyakarta. 